\title{
Experiential Learning: Lessons Learned From The UND Business And Government Symposium
}

Dana Michael Harsell, University of North Dakota, USA Patrick B. O'Neill, University of North Dakota, USA

\begin{abstract}
The authors describe lessons learned from a limited-duration experiential learning component of a Master's level course. The course is open to Master's in Business and Master's in Public Administration students and explores the relationships between government and business. A complete discussion of the Master's in Business and Master's in Public Administration students is presented, with emphasis on advance planning and integration of a limited-duration field trip experience into the academic component of the course.
\end{abstract}

Keywords: Experiential Learning; Limited-Duration Field Trip; Government and Business Interactions

\section{INTRODUCTION}

$\mathcal{J}$

his paper provides practical suggestions and lessons learned for integrating a limited-duration experiential field trip experience into a graduate-level course open to Master's in Business and Master's in Public Administration students at the University of North Dakota. The course, entitled Business and Government, is designed to broaden student awareness of the interrelationship between business and government in the United States and the importance of this interrelationship in an era of globalization. It introduces public and business administration students to the role of government in advancing, as well as regulating, business. Further it discusses ways that business can and does influence government decisions. It also looks at the ethical responsibilities of business and government in society. An integral component of the course involves travel to Washington D.C. to meet with political officials, including members of the state's congressional delegation and their staff; government agencies and regulatory agencies (prior trips included the General Services Administration, the International Trade Administration, and the Federal Communications Commission); and national and international business representatives (prior visits included visiting members of trade associations and lobby organizations and legislative affairs personnel from national business firms and Fortune 500 companies).

\section{THE ROLE OF EXPERIENCE IN LEARNING}

Scholars employ a number of terms to identify the "process of learning from experience" (Gentry, 1990, 10), one of which is "experiential learning". A synthesis of the literature by Ives and Obenchain (2006) revealed three core elements of experiential education curricula. First, opportunities must exist for students to engage in selfdirection. Second, the curriculum must present connections to the real world, and third, students must be allowed to engage in critical reflection of their experience. Educators may employ a variety of different educational tools to promote an experiential learning component within their curriculum. These tools include--but are not limited to-internships, service learning and field trips (see Wright, 2000). One outcome of experiential education is to provide opportunities for students to bridge the gap between theoretical knowledge and practice (see McCarthy and McCarthy, 2006).

Experiential learning is increasingly recognized as a critical component of a well-rounded graduate education curriculum. The Master's in Public Administration (MPA) and Master's in Business Administration 
(MBA) accreditation bodies both encourage experiential learning in their respective fields. For business students, experiential education is recognized for incorporating learning from the "real world" (Gentry, 1990), a way to achieve 'hands on' learning in Business Education (Sutton-Brady, 2008) and a method for creating a "critical intersection between classroom and business learning that keeps faculty and students connected to rapidly changing business models" (Association to Advance Collegiate Schools of Business, 2002). For students of public administration, Cunningham (1997) argues that experiential learning models better equip students to "manage the public's business." The role of experiential learning also remains one of the "big questions of public administration education" (Denhardt, 2000).

However, providing experiential learning opportunities remain a perennial challenge for graduate programs. While experiential learning and its theoretical antecedents enjoy vibrant scholarly discourse, McCarthy \& McCarthy note that "experiential programs are not a required part of the business curricula of many colleges and universities" (2006, 202). From an instrumental standpoint, limited-duration field trips offer a practical solution to increase experiential education opportunities in both MBA and MPA curricula. Demonstrably, limited duration field trip experiences can help achieve hands-on experiences in business education (Sutton-Brady, 2008), connect "classroom and community" (Jakubowski, 2003, 24) and expose students to "lived social events that become ways of knowing" (Scarce, 1997, 219). Thus, when integrated into a course, field trips can help students bring their exposure to classroom theory to bear on real-world applications.

\section{OVERVIEW OF COURSE}

The Business and Government Symposium offered at the University of North Dakota presents graduate students with a significant opportunity to learn the nuances of the relationships between government and business through the integration of classroom experience and a limited duration field trip. Highlights of the trip include meeting and observing officials in the public, private and non-profit sectors. It is thought that MBA and MPA students who better recognize the increasingly mutual interrelations between the public and private sectors will be more prepared to deal with these challenges upon accepting employment in their respective sectors. To help achieve these outcomes, the course can be loosely divided into three parts. The weeks leading up to the field trip have a strong theoretical component. Students begin the course by reflecting on a simple question to set the tone of the course and promote critical thinking and dialogue: "Business and government: friend or foe?" The instructors provide students with a number of readings to prepare them for the trip and to help identify when business and government interests are compatible or at odds with one another. Topics include a history of markets, regulatory theory, lobbying from a political science perspective and lobbying from a market or business perspective. This first part of the course is largely structured to provide a theoretical groundwork that students can later challenge, augment or verify through empirical observation. A representative syllabus is presented as an Appendix below.

The second part of the course involves the trip to the nation's Capitol during spring break. The field trip experience begins Sunday with an optional tour of Washington and a welcome reception Sunday evening. Monday and Tuesday are devoted to meeting with business and not-for profit interests, trade associations and lobby groups. Wednesday is set aside to meet with the state's congressional delegation, their staffers and committee staffers. The final day of the trip is usually convened in an office setting where some of the week's guests meet with us to offer some final thoughts on the business and government relationship and to help facilitate a reflective discussion of what students learned or observed. During the trip, students are required to maintain a daily journal of their experiences, which is a demonstrated technique to integrate the classroom and field trip experiences (Jakubowski, 2003).

The third component of the course emphasizes the integration of the classroom and field trip experiences through debriefing sessions, lecture and seminars and written and oral assignments. These assignments include writing a reflective paper on the experience (using the trip journal as a reference) and a final cumulative project and presentation. One example of previous final projects asked students to assume the role of a legislative affairs director (or lobbyist) and prepare a comprehensive press-kit on a public policy question; another project asked students to prepare and deliver testimony from the vantage points of business leaders and government agencies in a mock Senate committee hearing. 


\section{LESSONS LEARNED}

Based on student evaluations and instructor experience, the authors are in a position to offer some of the lessons learned when planning a limited duration field trip experience that may be applicable to a number of business related or and government related courses. These lessons can be broken into four parts: organizing the course, organizing the trip, executing the trip and post trip. While our specific course trip involves a week in Washington DC, these lessons are applicable to any field trip experience.

\section{Organizing the Course}

1. When possible, cross list the course with other disciplines. The partnership between the MBA and MPA disciplines provide a rich set of views. Each group of students challenges the other to see things from a different perspective. This is one of the most important pedagogical features of the course.

2. Include a mix of public agency personnel and private agency personnel during the trip. MPA students typically want more government and MBA students want more private business meetings. Keeping each group asking for more is a sure indication that you have created a well-balanced learning experience.

3. Prepare the Students for the trip. Assign books or readings that provide an academic or theoretical overview of the interactions between business and government. In this course, students prepare for the trip through readings and discussions that center on the history and role of markets, public policy, and lobbying from both the political science and business perspectives. By virtue of their own experiences, our practitioners will frequently describe and reinforce aspects of the readings during their talks. These realworld examples provide excellent opportunities during the trip debrief to discuss where theory intersects with practice.

4. Require students to research your contacts. Show students how to navigate organization websites and point them in the direction of pertinent trade journals. Students should research the mission statements for all the organizations they visit. Many of our contacts have public biographies; have students search for them and distribute them to each other.

5. Preparation for the trip should include a discussion about professional conduct, networking and sartorial choices. Equip the students with tools of the trade, such as business cards. The trip can be a prime opportunity for students to network or even to gain future employment. The instructors do not sell the trip as an opportunity to find employment as this might dilute the purity of the trip; however, at times our contacts have provided us information about internship and employment opportunities.

\section{Organizing the Trip}

1. Start planning early. Communicate with your contacts at least 8-12 weeks in advance; this gets your class trip "on their radar." Though, do not be surprised if you are asked to call back much closer to the trip to setup or to confirm an appointment.

2. Make sure to take advantage of the trip location. For example, during our trip to DC we try to work in a visit with our Congressional delegation as well as a tour of the Capital building.

3. People can be very generous with their time especially when meeting with students. Keep in mind that your contacts are also very busy and might become unavailable at a moment's notice. Be prepared to reschedule your meeting times.

4. Practice what you preach. One of the aspects of the course involves networking. Leverage connectionsgo through the alumni lists. Look for former students, but don't be afraid to "cold call" to set up a meeting time. When a class has a particular interest, the instructors have responded by trying to arrange a meeting with an appropriate agency, non-profit entity, trade association or business.

5. Partner with the school's alumni association. The trip provides an opportunity for your alumni office to host a reception. We have found that alumni typically enjoy meeting current students.

\section{The Trip}

1. Go to organizations rather than have them come to you. An important but sometimes undervalued learning experience is actually seeing where people work. The contrast between public sector and private 
sector office spaces can be quite illuminating (and not infrequently entertaining - as private sector organizations sometimes "put on a spread" for the students).

2. Limit the size of the class. Many organizations have limited space for visitors; we have found that a group larger than 14 (including the instructors) is too big.

3. Wear the students out. This is not play time. Pack the schedule so that students get a sense of the stress they might experience in the work world. If you hear the students complain that they are tired - you know you have successfully planned the day.

4. Try to group blocks of meetings in the same general area. This may be difficult, but this level of preparation can cut down on travel time between meetings and decreases the chance you will arrive to one of the meetings late.

5. Stage the trip. Instructors should arrive early and make a dry run. Appointment times might be tight, but arriving late to an appointment can make a negative impression.

6. Encourage questions from your students. The students are the focus of the trip. Make sure they put their research to good use by encouraging or requiring them to ask well-informed questions.

7. Require students to journal their experiences. This provides material from which the students can write a follow-up paper and allows them to more effectively critique the field trip experience.

8. Don't forget to exchange business cards! This is an important, yet often overlooked detail that will help facilitate thank-you notes, future contacts and future meetings.

\section{Post Trip}

1. Debrief. Take an entire class period to discuss the trip and to tie in some of the concepts they studied before the trip. Encourage students to reflect on their experiences and to comment on the extent to which their experiences or observations were in line with the course readings, lectures and discussions.

2. Evaluate. Pass out evaluations so students can give you feedback on the experience. This will also help determine who you contact for a subsequent trip.

3. Take care of business. Take some time during the debriefing to write thank-you cards to your contacts. This is good etiquette; it gives students another opportunity to network and it helps instructors maintain a relationship with their Washington contacts.

4. Reconcile theory and practice. This is perhaps the key piece of the experiential learning experience. Spend a portion of the remaining weeks engaging what they saw and learned, either in discussions or in a paper. Also, ask students to challenge their preconceived notions about government and business. How did their opinions or attitudes change as a result of the trip?

\section{CONCLUSION}

The foregoing lessons learned reflect the hindsight and experiences gained from planning and executing seven annual trips. Student feedback generally reflects positive experiences from the course and the field trip component. Examples include "I thought everything covered was very useful and informative and helped grasp a better perspective of overall government and business relations, especially at the federal level", "great course, incredible learning opportunity", and "It has been the best and most practical part of the program." The few negative comments about the trip tend to center on the costs associated with the trip, the price of the hotel stay or the exhausting pace of the week.

Conducting a limited duration field trip experience during a graduate level course is intensive and timeconsuming. Gremler, et. al. $(2000,36)$ caution that just because "students take on additional responsibility in the learning process during experiential activities, this does not imply that the instructor has less work to do." Indeed, successful field trips must be an integral component of the course; it cannot be auxiliary (Sutton-Brady, 2008). And linking aspects of the trip to the course outcome objective requires additional planning. However, the authors feel that instructors who integrate a limited duration field experience of this nature into their course will find the effort worthwhile in terms of the additional learning opportunities available to their students. 


\section{AUTHOR INFORMATION}

Dana Michael Harsell is an assistant professor of political science and public administration at the University of North Dakota. He teaches courses in American government, public administration and management, and state and local government. Dr. Harsell holds a BA in political science and psychology and an MA in political science, both from the University of Montana, and a PhD in political science from Syracuse University. Dana's research interests include public management, government performance and accountability, public service provision, and teaching methods in political science and public administration.

Patrick B. O'Neill is professor and chair of the Department of Economics at the University of North Dakota. He teaches courses in principles of macroeconomics, microeconomic theory, and managerial economics. He holds a BA in economics from the University of St. Thomas (St. Paul, MN) and an MA and PhD in economics from Boston College. His research interests include the teaching of economics, the theory of the firm, and the intersection of economics and ethics.

\section{REFERENCES}

1. Association to Advance Collegiate Schools of Business, Management Education at Risk, Report to the Management Education Task Force to the AACSB International Directors, 2002. Available Online at: http://www.gfme.org/issues/pdfs/Management Education at Risk.pdf Accessed: October 1, 2009.

2. Cunningham, Bob, Experiential Learning in Public Administration Education, Journal of Public Administration Education, Vol. 3, No. 2, pp. 219-227, 1997.

3. Denhardt, Robert B., The Big Questions of Public Administration Education, Public Administration Review, Vol. 61 No. 5, pp. 526-534, 2001.

4. Gentry, James W., “What is Experiential Learning?” In, James W. Gentry (ed.), Guide to Business Gaming and Experiential Learning, Nichols/GP Publishing, East Brunswick, 1990.

5. Gremler, Dwayne D., Experiential Learning Exercises in Services Marketing Courses, Journal of Marketing Education, Vol. 22, No. 1, pp. 35-44, 2000.

6. Ives, Bob and Kathryn Obenchain, Classroom and Academic Outcomes: For Those who Want it All, Journal of Experiential Education, Vol. 29 No. 1, pp. 61-77, 2006.

7. Jakubowski, Lisa Marie, Beyond Book Learning: Cultivating the Pedagogy of Experience through Field Trips. The Journal of Experiential Education, Vol. 26, No. 1, pp. 24-33, 2003.

8. McCarthy, Patricia R. and Henry M. McCarthy, When Case Studies are not Enough: Integrating Experiential Learning Into Business Curricula, Journal of Education for Business, Vol. 81 No. 4, pp. 201204, 2006.

9. $\quad$ Scarce, Rik, Field Trips as Short-Term Experiential Education. Teaching Sociology, Vol. 25 No. 3, pp. 219226, 1997.

10. Sutton-Brady, Catherine, Achieving Relevance in Assessment through Fieldtrips. College Teaching Methods \& Styles Journal, Vol. 4, No. 4, pp. 1-6, 2008.

11. Wright, Mary C., Getting More out of Less: The Benefits of Short-Term Experiential Learning in Undergraduate Sociology Courses. Teaching Sociology, Vol. 28, No. 2, pp. 116-126, 2000. 


\section{APPENDIX}

\section{Course Syllabus}

Selected segments of the most recent course syllabus (from Spring 2009) are presented here.

\section{COURSE OVERVIEW}

This course is designed to make students aware of the interrelationship between business and government in our society and the importance of this interrelationship in an era of globalization. It introduces public and business administration students to the role of government in advancing, as well as regulating, business. Further it discusses ways that business can and does influence government decisions. It also looks at the ethical responsibilities of business and government in our society. A component of the course involves travel to Washington D.C. to meet with political officials, e.g., the congressional delegation; legislative staff; government regulatory agencies, e.g., the federal communications commission; government advocacy agencies, e.g., Department of Commerce; and national and international business representatives.

\section{COURSE OBJECTIVES}

At the end of the course, the student should be able to

- $\quad$ Recognize and comprehend the complex business-government nexus in the US economy

- $\quad$ Describe numerous US regulatory agencies and acts

- $\quad$ Understand and appreciate the role of lobbying in the US economy

- Speak intelligently about corporate and government social responsibility

- Share some great stories about your experiences in our nation's capital

\section{READING MATERIAL}

1. Books

- $\quad$ John McMillan, Reinventing the Bazaar: a natural history of markets (JM)

- $\quad$ Jeffrey M. Berry and Clyde Wilcox, The Interest Group Society, 4e (BW)

- $\quad$ Michael Watkins, Mickey Edwards, and Usha Thakrar, Winning the Influence Game (WET)

- $\quad$ Robert F. Bruner and Sean D. Carr, The Panic of 1907 (BC)

2. Handouts

Several articles will be handed out or links provided and posted on Blackboard.

\section{COURSE PROCEDURE}

The format for each class will be a combination of lecture and discussion. At times your instructors will present material; at times you will present material; at times discussion will occur. You should come to each class prepared by having read the material for that day and formulated one or more questions designed to stump your professors.

\section{THE TRIP}

A significant component of the course is a field trip experience in Washington DC during March 14-19, 2009. THIS IS A REQUIREMENT - NOT AN OPTION. This will be discussed early and often. Many versions of the agenda will be handed out prior to your being in possession of the final agenda. 


\section{COURSE PROJECT ASSIGNMENT}

The course project assignment will build on the concepts that we have studied over the semester. The project will focus on the financial sector crisis in our economy. We will simulate a hearing before the Senate Banking, Housing and Urban Affairs Committee. Your instructors and invited guests will be the Committee members. In teams of two you will appear before this committee as a representative of one of the following stakeholders:

- Small community banks

- $\quad$ Large commercial banks/investment banks/FHCs

- Insurance companies

- $\quad$ The Big 3 US auto manufacturers
- $\quad$ The SEC

- $\quad$ The Fed

- $\quad$ The US Treasury

During your time before the Committee you will deliver your prepared remarks and respond to any questions. You will also be given some questions by the Committee to which you will be required to prepare and submit written responses. There are several parts to this assignment, each with a separate due date.

\section{Part 1 Prepared Remarks for the Committee}

Your time before the committee will consist of approximately 15-20 minutes. For the first 5-7 minutes you will present your prepared remarks. The remaining time will consist of questions by the Committee and answers by you. Your prepared remarks should be 2-3 pages in length and turned in on Friday 1 May 2009.

\section{Part 2 Policy Briefing Kit}

As a part of your overall analysis, you will be required to compile a Policy Briefing Kit consisting of:

\section{Contents}

\section{Suggested Length}

1. Cover letter to the Committee

2. Executive Summary of policy issue(s)

3. $\quad$ Copy of your prepared remarks

4. Policy primer or 'backgrounder'

1 page

No more than 1 page

2-3 pages

3-5 pages

The Policy Briefing Kit is due at the beginning of the Committee Hearing on 4 May 2009.

\section{Part 3 Response to Committee Questions}

After your hearing you will be required to write up a response to questions and/or requests for further information from the Committee. This is to be turned in on 11 May 2009 
NOTES 